\title{
I Reunião de Diretores e Chefes de Pessoal do Serviço Público Civil da União
}

\section{AS FINALIDADES DO ENCONTRO}

\section{A}

implantação da Reforma Administrativa na área de pessoal torna indispensável a adoção de uma nova política, a fim de que os órgãos integrantes da referida área passem a atuar dentro dos principios estabelecidos pelo Decreto-lei $n^{\circ}$ 200, de 25-2-67.

Esses principios que se acham compendiados no Título XI do referido decreto-lei devem traduzir-se em providências de ordem prática e estas importarão, necessàriamente, em substanciais modificações no sistema de pessoal ora em vigor. Dessas modificações as mais urgentes e, ao mesmo tempo, mais importantes dizem respeito: a) à revisão da estrutura do sistema em vigor; $b$ ) à reformulação do esquema de competência e dos métodos de funcionamento dos órgãos integrantes to sistema.

Providências como as acima indicadas afetarão o sistema de pessoal em conjunto, atingindo cada uma de suas peças, pelo que se faz imprescindivel um trabalho prévio de esclarecimento e de análise da situação existente, a fim de que todos os órgãos interessados na matéria possam situar-se, acertadamente, em relação ao problema, e definir em têrmos claros a colaboração que, mùtuamente, deverão prestar uns aos outros.

Com êsse objetivo, o DASP, na sua qualidade de órgão central do sistema de pessoal responsável pelo estudo, formulação de diretrizes, orientação, coordenação e contrôle tus z.ssuntos concernentes à Administração do Pessoal Civil da União (art. 115, do Decreto-lei $n^{\circ}$ 200/67), promoveu no período de 6 a 8 de aqussto de 1969, em Brasilia, a I Reuniâo de Diretores e Chefes de s'essoal do Serviço Público Civil da União.

\section{ESQUEMA DE FUNCIONAMENTO}

Compareceram especificamente: 1) Os Diretores de Pessoal dos Ministérios e os Chefes de Pessoal dos Órgãos básicos vinculados, cujo comparecimento foi considerado indispensável pelo 
respectivo Ministro; II) Os Diretores e Chefes de Pessoal dos Órgãos de Assessoramento imediato do Presidente da República; III) Os Diretores das Divisões de Classificações de Cargos, Regime Jurídico, Seleção e Aperfeiçoamento, bem como os Consultores Jurídicos do DASP; IV) Autoridades e Técnicos especialmente convidados pelo DASP cuja presença foi julgada útil ao pleno êxito da Reunião para consultas eventuais ou assessoramento especializado.

Inúmeros Diretores e Chefes de Pessoal apresentaram por escrito, de maneira sucinta e objetiva, sumários ou resumos das respectivas intervenções ou pronunciamentos como subsídios ao aproveitamento posterior e divulgação. Essa providência contribuiu sobremaneira para uma melhor disciplina dos trabalhos e preparo da documentação final que será coordenada pelo DASP.

\section{REUNIAO DE DIRETORES E CHEFES DE PESSOAL DO SERVIÇO PÚBLICO DA UNIÃO}

Programação:

Data: 6,7 e 8 de agôsto

Local: Auditório do DASP Esplanada dos Ministérios - Bloco 7 $-5^{\circ}$ andar - Brasília

\section{1\% DIA}

6 de agôsto

Às 9,00 horas

Sessião Preparatória

- Apresentação de credenciais

- Distribuição dos Documentos de Trabalho

- Recomendações pelo CoORDENADOR

Das 14,00 às 15,30 horas

SESSÃO SOLENE DE ABERTURA DA REUNIÃO, POR SUA EXCELENCIA O SENHOR MINISTRO DO PLANEJAMENTO E COORDENAÇÃO GERAL, DR. HÉLIO BELTRAO

- (Tema da Exposição do Ministro Helio Beltrã̃o - Filosofia e Política de Pessoal do Govêrno da União).

Das 16,00 às 18,00 horas

- Exposição, pelo Senhor Diretor-Geral do DASP, Pro-

fessor Glauco A. Lessa de Abreu e Silva, sôbre a Proble- 
mática da Reunião e seus objetivos - A Importância dos Órgãos de Pessoal na Integração do Sistema - O DASP como Órgão de Formulação de Diretrizes, Coordenação, Supervisão e Contrôle do Sistema. Inicio da Integração. Primeiros Instrumentos: CADASTRO (Decreto n: 64.564, de 22-5-69), ENQUADRAMENTO E READAPTAÇ.ÃO (Decreto-lei $n^{\circ}$ 625, de 11-6-69).

\section{DIA}

7 de agôsto

Das 9,00 às 10,15 horas

- Exposição, pela Sra. Vera da Silva Medeiros, Diretora do Serviço de Documentação do DASP, sôbre o Papel da Documentação na Implantação da Nova Politica de Pessoal. Análise do Boletim Informativo DIRETRIZES (Legislação e Orientação Administrativa) .

Das 10,30 às 12 horas

Sessĩ̃o dE Trabalho

- Exposição, a cargo do Dr. Waldyr dos SAntos, Diretor da Divisão do Regime Jurídico do Pessoal, sôbre a participação da DRJP na implantação da Reforma Administrativa.

Das 14,00 às 18,00 horas

- Recolhimento de sugestões relativas ao Boletim Informativo DIRETRIZES (Legislação e Orientação Administrativa), seguido de debates sôbre as questões abordadas na Exposição do Dr. Waldyr Dos Santos, com a participação de todos os presentes à Reunião.

3० DIA

8 de agôsto

Das 9,00 às 12,00 horas

- Exposição, a cargo do Professor Raimundo XAvier DE Menezes, Diretor da Divisão de Classificação de Cargos do DASP, sôbre ENQUADRAMENTO E READAPTAÇÃO. imediatamente seguida de Seminário para discussão dos problemas versados.

Das 14,00 às 17,30 horas

SESSAO DE ENCERRAMENTO, SOB A PRESIDENCIA DO DIRETOR-GERAL DO DASP.

- Nessa oportunidade foram escolhidos os temas básicos colimados pela REUNIÃO e designadas as respectivas Comissões. Balanço e avaliação das Conclusões e Recomendações obtidas para exame de sua viabilidade e consideração posterior pela II REUNIAO, a ser oportunamente realizada.

Às 18,30 horas

- COQUETEL no Gabinete do Diretor-Geral do-DASP. 